\title{
Processing and microbiological characterization of diet strawberry ice cream with addition of whey protein concentrate, whole milk powder and sweeteners
}

\author{
Celeide Pereira ${ }^{1,2, *}$, André Andrejewski ${ }^{2}$, Ademir Mattana ${ }^{2}$, Carla Adriana Pizarro Schmidt ${ }^{2}$, \\ Pedro Luiz Manique Barreto ${ }^{1}$, Ernani Sebastião Sant Ánna ${ }^{1}$ \\ ${ }^{1}$ Federal University of Santa Catarina State - SC, Brazil \\ ${ }^{2}$ Federal Technological University of Paraná, Medianeira Campus - PR, Brazil

\section{Email address:} \\ celeidep@yahoo.com.br (C. Pereira), aandrejewski@hotmail.com (A. Andrejewski), mattanautfpr@yahoo.com.br (A. Mattana), \\ carlaschmidt@utfpr.edu.br (C. A. P. Schmidt), barreto@cca.ufsc.br (P. L. M. Barreto), ernanis@cca.ufsc.br (E. S. S. Ànna)
}

\section{To cite this article:}

Celeide Pereira, André Andrejewski, Ademir Mattana, Carla Adriana Pizarro Schmidt, Pedro Luiz Manique Barreto, Ernani Sebastião Sant Ànna. Processing and Microbiological Characterization of Diet Strawberry Ice Cream with Addition of Whey Protein Concentrate, Whole Milk Powder and Sweeteners. International Journal of Nutrition and Food Sciences. Vol. 3, No. 2, 2014, pp. 97-103. doi: $10.11648 /$ j.ijnfs.20140302.22

\begin{abstract}
Ice cream is not considered to be a serious source of bacterial infection since it is a frozen food product, the greatest risk of contamination occurring during the processing stage. The aim of this study was to determine and evaluate the microbiological characteristics of diet strawberry ice cream formulations with the addition of whey protein concentrate (WPC), whole milk powder (MP) and sweeteners. The formulations were prepared in two stages: in the first stage ice cream samples were prepared with WPC and either stevia (F1), sucralose/acesulfame-K (F2), saccharin/cyclamate (F3) or fructose (F4) and with MP but without sweeteners (F5); and in the second stage ice cream with the addition of MP (F1-MP) or WPC (F2-WPC) with sucralose/acesulfame-K were prepared. The pasteurized milk, cream and ice cream were submitted to analysis to determine the counts for viable aerobic mesophylls, coliforms at $35{ }^{\circ} \mathrm{C}$ and $45^{\circ} \mathrm{C}$, psychrotrophic bacteria, coagulase-positive Staphylococcus aureus and molds and yeasts. A study on the presence of Salmonella spp. was also carried out. All of the analysis was carried out in triplicate. The pasteurized milk, cream and ice cream had good microbiological quality, indicating strict control during all processing stages, leading to a high quality product.
\end{abstract}

Keywords: Edible Ices, Food Safety, Processing Control

\section{Introduction}

Ensuring the safety and quality of food products is essential to public health, making it necessary that these issues constitute a reference for the food industry, particularly for dairy products. A great variety of microorganisms colonizes and grows in common food products. Many products provide an environment suitable for the growth of microorganisms, reducing the product quality and the availability of these products to the consumer. The deterioration of food products is defined as any alteration in the appearance, odor or taste of a food product which makes it unacceptable to the consumer. Foods which have deteriorated do not necessarily pose a risk to the consumer; however, in some cases, pathogenic organisms may be responsible for the deterioration [1].
Food safety currently represents a challenge and needs to be considered throughout the food chain [2]. The microbiological examination of a food product can be carried out, among other reasons, to verify its microbiological quality or to ascertain that it satisfies certain microbiological criteria. Indicator microorganisms have been researched in order to verify the hygiene-sanitary quality of food products and the results of microbiological analysis indicate the quality of the raw materials employed, the cleanliness of the food preparation conditions and the efficiency of the preservation method [3].

Several microorganisms can cause problems when present in food products, both financially and in terms of health. These include the group of microorganisms called coliforms (total or thermotolerant), Staphylococcus aureus, filamentous fungi and yeasts and Salmonela spp. A characteristic of 
coliforms is that they can ferment lactose with the subsequent formation of gas. The main microorganism which represents this group is Escherichia coli, which lives in the intestine of warm-blooded animals. Thus, the detection of these bacteria can indicate fecal contamination. The species Staphylococcus aureus is frequently related to cases and outbreaks of food poisoning, due to the ability of most strains to produce enterotoxins. Given the risk to public health and the importance which the presence of enterotoxins in food products represents, in several countries the research and quantification of this species is obligatory and established as part of the sanitary inspection policies of governmental bodies [4]. Filamentous fungi and yeasts when present in food can lead to the loss of the product. Although the pathogenic action of these microorganisms is not common in dairy products, they still represent a health risk to consumers [5]. Salmonella spp. are widely distributed in nature and the intestinal tract of humans and other animals is their main natural reservoir. These are the main agents of diseases originating from food in various parts of the world, including Brazil. These bacteria reach the whole chain of food production, and have been found in many industrialized products [6].

Products based on milk, such as ice cream, are currently considered functional ingredients in relation to health. They contain proteins, sugars, vegetable and/or animal fat, vitamins $\mathrm{A}, \mathrm{B} 1, \mathrm{~B} 2, \mathrm{~B} 6, \mathrm{C}, \mathrm{D}$, and $\mathrm{K}$, calcium, phosphorous and other essential minerals in a balanced proportion. The chemical composition of ice cream basically comprises the following ingredients: $10 \%$ to $17 \%$ fat, $8 \%$ to $12 \%$ dry defatted extract, $12 \%$ to $17 \%$ sugars, $0.2 \%$ to $0.5 \%$ stabilizers and emulsifiers and $55 \%$ to $65 \%$ water [7].

The Brazilian Resolution RDC n. 266 of 09/22/05 [8] defines edible ices as "frozen products obtained from an emulsion of fats and proteins; or from a mixture of water and sugar(s) to which (an) other ingredient(s) can be added so long as this does not change the nature of the product." This food product is one of the milk derivatives most appreciated by the population in general [9].

The growing demand for food products which are ever more nutritive, accessible and associated with a low production cost makes whey an important source of essential nutrients, which can be easily obtained and employed in the preparation of a large number of food products [10].

Whey protein concentrate (WPC) is a product obtained from the processing of milk whey and is commercialized in the form of a powder [11].The protein content of WPCs can vary between $35-80 \%$. When WPCs contain around $53 \%$ of protein there will be on average $35 \%$ of lactose, $5 \%$ of fat and $7 \%$ of ash content. However, on increasing the protein concentration to $80 \%$ the content of lactose decreases to around $7 \%$, and the fat and ash contents to between $4 \%$ and $7 \%$, respectively [12].WPC confers functional and nutritive properties of interest to yogurt, cream, butter, ice cream, cream cheese and other products, which are of the 'light' version and differ in terms of cost $[13,14]$.

A variety of products has appeared on the market aimed at replacing sucrose in dairy products, as a result of the growing concern regarding the needs of people with metabolic problems, such as diabetes, to reduce their sugar consumption [15]. Sweeteners are used as sucrose substitutes by the food industry, or even domestically by consumers, in the preparation of diet or light food and drink products, since some sweeteners are not metabolized by the organism and thus do not provide calories, while others, even though they provide energy, guarantee insignificant calorific value because they are used in insignificant quantities [16].

The association of ice creams with the transmission of disease has been frequently demonstrated in countries where strict food control is in place. Ice cream can act as a vehicle for several pathogens, due to poor pasteurization, contamination during preparation, inadequate storage, distribution, raw material contamination and a lack of hygiene associated with the machines and utensils [17].

Ice creams are not considered to be a serious source of bacterial infection since they are a frozen food product. However, resistance to microorganisms on freezing is highly variable, since freezing does not necessarily provoke the death of all microorganisms present and many survive in different physiological states [18, 19].Most cases of ice cream contamination involve microorganisms which reach the food product during processing, from the selection of raw materials to the final operation when the product is ready for consumption. The materials used in the preparation of ice cream can contain a high number of bacteria which can survive the pasteurization phase when this is not properly carried out. The addition of fruit, nuts, chocolate, coloring and flavoring, among other ingredients, is an important factor in relation to the contamination of the product. If a problem occurs in this phase and appropriate disinfection (pasteurization) does not occur, bacteria may survive and proliferate, leading to a serious health risk, even when the product is maintained under refrigeration or freezing conditions, since there will not be total inhibition of the remaining microorganisms[20, 21, 22].Thus, it can be concluded that a food product which requires extensive manipulation has a higher chance of becoming contaminated, if aseptic conditions are not observed during processing [23].

The aim of this study was to prepare diet strawberry ice creams with whey protein concentrate, whole milk powder and sweeteners (stevia, sucralose/acesulfame-K saccharin/cyclamate or fructose) and to evaluate the microbiological characteristics of the ice creams, in order to obtain a low cost product with high nutritional and functional value, low calorific value and high microbiological quality.

\section{Materials and Methods}

Ice cream samples were prepared at the Dairy Laboratory and the microbiological analysis was performed at the Microbiology Laboratory, both at the Federal Technological University of Paraná State - Medianeira Campus.

The ice cream samples were prepared using the discontinuous process [24], and the processing stages are 
detailed in the flowchart shown in Figure 1.

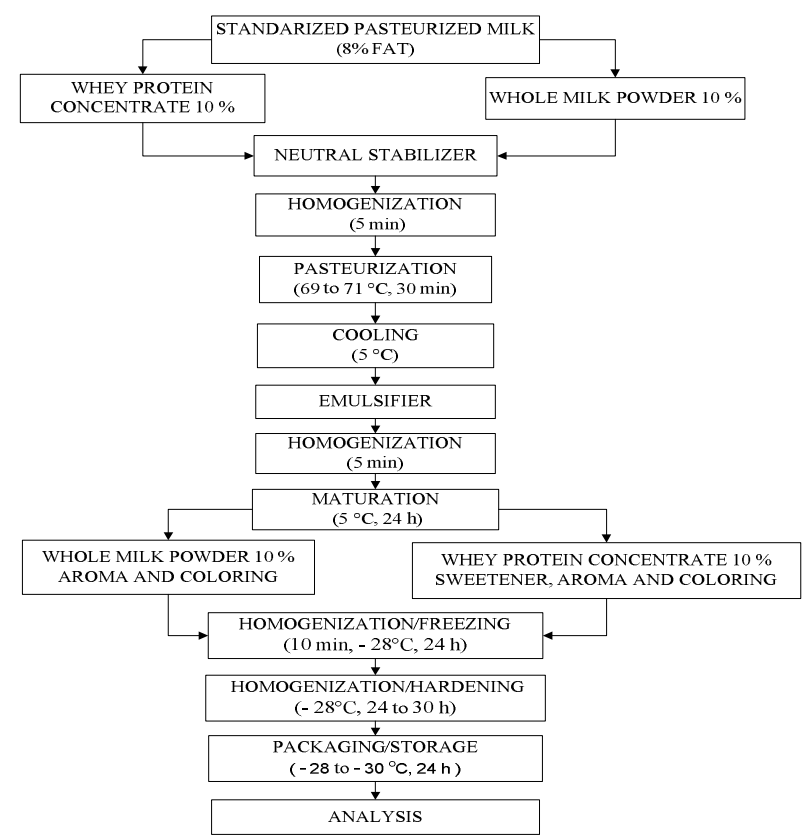

Figure 1. Flowchart of the processing of ice cream samples with whole milk powder (MP) and with whey protein concentrate (WPC).

The basic mixture of the formulation of each ice cream sample comprised 2 liters of homogenized pasteurized milk, cream (used to standardize the milk), whole milk powder (Nestlé), whey protein concentrate (WPC) (CPSs ${ }^{\circledR}$, Sooro, Brazil), the stabilizer Super Liga Neutra ${ }^{\circledR}$ (Duas Rodas, Brazil), the emulsifier Emustab ${ }^{\circledR}$ (Duas Rodas, Brazil), sweeteners (stevia, fructose, sucralose/acesulfame-K, saccharin/cyclamate ${ }^{\circledR}$ (Gemacon, Brazil)), strawberry flavoring (Algemix ${ }^{\circledR}$, Duas Rodas, Brazil), cochineal carmine coloring (carmin de colchonilha ${ }^{\circledR}$, Gemacom, Brazil) and strawberry aroma (Aroma de Morango ${ }^{\circledR}$, Givaudan, Brazil). Five different ice cream formulations were prepared, all standardized to comprise $8 \%$ fat, and codified as follows: with WPC and stevia (F1), with WPC and sucralose/acesulfame-K (F2), with WPC and saccharin/cyclamate (F3), with WPC and fructose (F4) and with MP and without sweetener (F5).

In the next stage, the ice cream formulation with sweetener which was closest to the ideal (sucralose/acesulfame-K) was then identified and selected for the preparation of two new formulations with whole milk powder (F1-MP) and with whey protein concentrate (F2-WPC), following the same procedures described for the production of the previous formulations. Microbiological analysis was carried out on the standardized pasteurized milk and the cream. In the case of the homogenized pasteurized milk analysis was performed to determine the counts for aerobic mesophylls, coliforms at $35^{\circ} \mathrm{C}$ and $45^{\circ} \mathrm{C}$ and psychrotrophic microorganisms. For the cream the counts for aerobic mesophylls, coliforms at $35^{\circ} \mathrm{C}$ and $45^{\circ} \mathrm{C}$, coagulase-positive Staphylococcus, psychrotrophic microorganisms and molds and yeasts were determined. All ice cream formulations were analyzed for coliforms at $45^{\circ} \mathrm{C}$, Salmonela spp./25g, coagulase-positive Staphylococcus aureus. All of the analysis of the homogenized pasteurized milk, cream and ice cream formulations were carried out according to the methodology described in the Brazilian Norm $\mathrm{n}^{\circ} 62$ [25]. The results were analyzed according to the Brazilian Resolution RDC 12 [26]. All of the analyses were carried out in triplicate.

\section{Results and Discussion}

The results obtained from the microbiological analysis of the homogenized pasteurized milk and cream are shown in Table 1.

Table 1. Results for the microbiological analysis of the standardized pasteurized milk and cream.

\begin{tabular}{lcc}
\hline Microbiological analysis & Pasteurized Milk & Cream \\
\hline Count for viable aerobic mesophylls $(\mathrm{CFU} / \mathrm{mL})(\mathrm{CFU} / \mathrm{g})$ & $<10$ & $<10$ \\
Count for coliforms at $35^{\circ} \mathrm{C}(\mathrm{CFU} / \mathrm{mL})(\mathrm{CFU} / \mathrm{g})$ & $<10$ & $<10$ \\
Count for coliforms at $45^{\circ} \mathrm{C}(\mathrm{CFU} / \mathrm{mL})(\mathrm{CFU} / \mathrm{g})$ & $<10$ & $<10$ \\
Count for psychrotrophic microorganisms $(\mathrm{CFU} / \mathrm{mL})(\mathrm{CFU} / \mathrm{g})$ & - & $<10$ \\
Count for coagulase-positive Staphylococcus aureus $(\mathrm{CFU} / \mathrm{g})$ & - & $<10$ \\
Count for molds and yeasts $(\mathrm{CFU} / \mathrm{g})$ & - & $<10$ \\
Presence of Salmonella spp./25g(CFU/g) & Absent in $25 \mathrm{~g}$ \\
\hline
\end{tabular}

All of the results for the analysis carried out on the homogenized pasteurized milk and cream adhered to the standards established by the current legislation [26]. The counts for the aerobic mesophylls were also within the standards required by law. A high count in milk may indicate, in general, inadequate quality of the product. This can be related to failures in the production practices and handling at the farm, the health of the dairy herd or the pasteurization process. The pasteurization of milk both to drink or for the production of cream and processing of products, reduces the risks of food toxinfections [27], however, failures during the processing and 
commercialization can adversely affect the microbiological quality of the product.

The absence of coliforms is a good indicator of the appropriate sanitary conditions of the food, thus, the pasteurized milk and cream were in satisfactory sanitary condition, demonstrating that the pasteurization was efficient and the handling adequate.

The absence of psychrotrophs in the products demonstrates that the pasteurization was efficient and the refrigeration process adequate, since these microorganisms are not resistant to pasteurization, according to [28]. Of the microorganisms which contaminate milk, the psychrotrophs are of great importance in relation to the quality of milk and its derivatives, due to the refrigeration of the product. After 48 hours of refrigeration these bacteria predominate and thus there is an intense production of proteases and lipases which degrade protein (mainly casein, being more sensitive to enzymatic action) and milk fat, respectively.

In relation to the molds and yeasts the results obtained adhered to the standards established in the current legislation [26]. [29]. Reported that filamentous fungi and yeasts are very important indicators of contamination in the milk production chain and can be considered to be a contamination factor when isolated from residual water on utensils and equipment. The presence of these microorganisms in a food product can reduce its shelf life, modifying its sensory characteristics and even its deterioration.
In the study on the presence of Salmonella spp. the cream did not show contamination, this result being satisfactory and of great importance since Salmonella spp. are responsible for many cases of gastroenteritis of food origin. Salmonella spp. are bacteria of enteric origin responsible for serious outbreaks of food infection, products of animal origin being the main transmission vehicles of these pathogens [30].

The results for the coagulase-positive Staphylococcus demonstrated good practices throughout the cream production process since, according to [31], milk and its derivatives are susceptible to contamination by different pathogenic microorganisms and their toxins, such as coagulase-positive Staphylococcus aureus which is one of the most common agents responsible for outbreaks of food intoxication. The presence of these microbes in milk and its derivatives may also originate from secondary contamination, since they can be found in the nasal cavity, mouth (saliva), digestive tract and skin of humans. Another factor associated with the presence of these bacteria is the fact that they produce thermostable toxins, which are not eliminated during the thermal treatment process carried out at the production plants (Ultra High Temperature (UHT) pasteurization), thus posing a threat to human health in the form of, for example, food intoxication [32].

The results obtained from the microbiological analysis of the five ice cream formulations are shown in Table 2.

Table 2. Results for the microbiological analysis of five formulations of diet strawberry ice cream produced with whey protein concentrate (WPC) and sweetener or with milk powder (MP) without sweetener.

\begin{tabular}{llllll}
\hline Microbiological Analysis & F1 & F2 & F3 & F4 & F5 \\
\hline Count for coliforms at $45^{\circ} \mathrm{C}$ (MPN/g) & $<2$ & $<2$ & $<2$ & $<2$ & $<2$ \\
Count forcoagulase-positiveStaphylococcus aureus (MPN/g) & $<10^{2}$ & $<10^{2}$ & $<10^{2}$ & $<10^{2}$ & $<10^{2}$ \\
Presence of Salmonella spp./25g (MPN/g) & absentin 25g & absentin 25g & absent25g & absentin 25g & absentin 25g \\
\hline
\end{tabular}

All of the formulations complied with the standards established in the current legislation which is set at $5 \times 10$ most probable number (MPN)/gfor the count for coliforms at $45^{\circ} \mathrm{C}$ [26]. According to [33], high quantities of coliforms in food products can indicate that they were prepared with highly contaminated raw material, that the processing was not carried out satisfactorily or that the food products were stored under inadequate conditions in terms of time or temperature. This was not demonstrated by the results obtained for these ice cream formulations. However, some studies carried out on ice creams can be cited where the results did indicate high counts for total coliforms above $10^{2} \mathrm{MPN} / \mathrm{g}$, for instance, [20,34, 35]. It is important to note that the larger the population of coliform bacteria the poorer the hygiene and processing conditions applied during the ice cream preparation and, consequently, the shelf life of the product will be reduced and the health risk to the consumer will increase.

The absence of coagulase-positive Staphylococcus aureus was verified for all of the ice cream formulations since good production practices were employed during their preparation. The presence of Staphylococcus aureus on ice cream production lines has be Staphylococcus aureus en considered as an indicator of precarious conditions of hygiene and the inappropriate handling of the raw materials and the final product [36]. Several studies have shown that personnel involved in the preparation are the main sources of food contamination $[27,37,38,39]$. The nasal passages, hands and other surfaces absent of lesions are the main reservoirs of coagulase-positive Staphylococcus aureus.

In relation to the results obtained for the study on the presence of Salmonella spp., all samples adhered to the Brazilian legislation [26], that is, the results showed that this bacteria was absent. The same result was obtained by [40], who analyzed thirty-six samples of ice cream based on milk produced by a small company in Piracicaba, São Paulo State, Brazil.[41]carried out the microbiological and physicochemical analysis of four different brands of ice cream based 
on milk in the city of Fortaleza, Ceará State, Brazil and verified the presence of Salmonella spp. in $75 \%$ of the samples and in $100 \%$ of samples the counts for Staphylococcus aureus were above the standards. According to [42], the application of Hazard Analysis and Critical
Control Points (HACCP) was of fundamental importance to reduce the incidence of pathogenic microorganisms in the ice cream industry.

The microbiological results for two ice cream formulations are shown in Table 3.

Table 3. Results for the microbiological analysis of two diet strawberry ice cream formulations with the addition of sucralose/acessulfame-K, produced with whole milk powder (F1-MP) or whey protein concentrate (F2-WPC).

\begin{tabular}{l|c}
\hline Microbiological Analysis & F1-LP \\
\hline Counts for coliforms at $45^{\circ} \mathrm{C}(\mathrm{MPN} / \mathrm{g})$ & $<2$ \\
Counts for coagulase-positive Staphylococcus aureus/g (MPN/g) & $<2$ \\
Presence of Salmonella spp./25g (MPN/g) & $<10^{2}$ \\
\hline
\end{tabular}

During the production of these formulations all of the good practices associated with the processing were applied in the production of the ice cream and this is verified by the results obtained for the coliform counts which adhered to the standards required by Brazilian legislation [26].The coliform bacteria are considered to be the main contamination agents associated with the deterioration of milk derivatives, causing abnormal fermentation of the products. It should also be noted that the counts for these microorganisms, mainly those of fecal origin, indicate the hygiene conditions in which the products were processed [43].The presence of high levels of coliforms is unacceptable and indicates the poor hygiene-sanitary conditions of food products and of the places where the products are prepared and/or stored. This problem frequently occurs during the handling of prepared food products and influences their shelf life and consequently their quality [41].

In the case of coagulase-positive Staphylococcus aureus, the results for the two formulations indicated the absence of this microorganism, demonstrating that the processing was adequate and indicating strict control during the preparation.[44],reported that during the processing of ice cream, direct handling by people, the main source of contamination by this microorganism, is not necessary. On the other hand, other authors have isolated coagulasepositive Staphylococcus aureus reporting high counts in ice creams, highlighting the potential risk of the contamination of this product. [17] observed the presence of Staphylococcus aureus in $10 \%$ of ice cream samples analyzed. The presence of staphylococcus enterotoxins in milk products has been noted in several studies and, according to [45], Staphylococcus aureus can produce toxins regardless of whether they are coagulase-positive or not.

The absence of Salmonella spp. was verified for all of the formulations demonstrating that good practices were observed during their production, including the timetemperature of pasteurization and the use of good quality ingredients, appropriate cleaning of the equipment used in the production of the samples, along with strict control during the handling of the samples throughout the processing procedure, aiming to obtain a product of high quality. According to the current legislation [26] the absence of Salmonella spp. indicates that the samples analyzed are appropriate for consumption. According to[46], even with the use of the pasteurization process to destroy the Salmonella spp. cells in the ice cream, the product can be re-contaminated by the utensils used in the production process and by the hands of the personnel carrying out the processing procedure. [47] also detected Salmonella spp. in ice cream at population levels of $2.0 \mathrm{x}$ $10^{6}, 3.7 \times 10^{5}$ and $4.2 \times 10^{4}$ in three samples studied. This demonstrates that the control of the ice cream processing should be strictly monitored in order to avoid cross contamination, which can lead to serious infection and make the product inappropriate for consumption. [48], studied the sources of the microbiological contamination of ice cream during processing and noted that personal hygiene, the prolonged use of equipment at inappropriate freezing temperatures, training personnel in the Good Production Practices (GPP) and HACCP are important points in the sanitary control of ice cream production. It should be noted that children are the greatest consumers of ice cream and special care should be taken from the choice of raw materials to the final stages of ice cream processing.

\section{Conclusions}

It can be concluded that the results of the microbiological analysis of homogenized pasteurized milk, cream and ice creams demonstrate the appropriate timetemperature of pasteurization, use of good quality ingredients and cleaning of equipment during the whole process. The monitoring of the quality of the initial raw material and control of the whole ice cream processing procedure was strict, with the aim of offering the consumer safety and confidence in relation to the buying of the product, which represents an alternative for the consumption of a food product of low calorific value and low cost which is nutritional and functional and also has good microbial quality.

\section{Acknowledgements}

We are very grateful to Financial support from the Frimesa; Alibra - Sooro; Kerry do Brasil; Candon Aditivos 
para Alimentos Ltda; Gemacon industries.

We also thanks Federal Technological University of Paraná - Medianeira Campus - PR, Brazil and Federal University of Santa Catarina State (UFSC) - SC, Brazil.

\section{References}

[1] Madigan, M. T., Martinko J. M. Parker J. Tradução Kiaw C.M (2004).Microbiologia de Brock. Pearson Education do Brasil, São Paulo. SP, $10^{\mathrm{a}}$ ed.

[2] Brito, G.G.A.P., Ferreira, D.N., Ramos, N. P., Silva, P. S., Silveira. E. O., Cabral, T. M. A and Nascimento, G. J. (2008). Aspecto sanitário de 10 amostras de doce de leite fabricado por uma indústria do município de João Pessoa PB. Anais do XI Encontro de iniciação à docência. In: Encontro de iniciação à docência. João Pessoa - PB.

[3] Franco, B. D. G. M., Landgraf, M. (2005). Microbiologia de Alimentos. 2. ed. São Paulo: Atheneu,. 182.

[4] Gandra, E. A. (2003). Identificação de Staphylococcus aureus, S. intermedius e S. hyicus através de testes bioquímicos e da amplificação por PCR de seqüências dos genes coa E nuc. UFP, Pelotas-RS, Brasil. Dissertação de Mestrado (Ciência e Tecnologia Agroindustrial).

[5] Silva, C. R., Barbosa, J. B., Firmino, F. C and Caldonelli, L. R. (2012). Qualidade microbiológica de requeijão e doce de leite pastoso produzidos em Tocantins - MG, Ciências Biológicas e da Saúde, v. 1, n.1, <http: seer persctivas on line.com.br $>$ Accessed on: 08 April.

[6] Peixoto, D., Weckwerh, P. H and Sinionato, E. M. R. S. (2009).Avaliação da qualidade microbiológica de produtos de confeitaria comercializados na cidade de Ribeirão Preto São Paulo, Alimentos e Nutrição Araraquara, 20:(4): 611615

[7] Trgo, C. (2003). Factors affecting texture of ice cream. In: MACKENNA, B. M. (Ed.). Texture in food: semi-solid foods. Boca Raton, FL: CRC Press, 1: 448.

[8] BRASIL, Secretaria de Vigilância Sanitária. (2005). Resolução RDC n. 266, de 22 de setembro de 2005. Aprova o regulamento gelados comestíveis e preparados para gelados comestíveis. Diário Oficial [da]República Federativa do Brasil, Pode executivo, Brasília, DF, 23 set.

[9] Alvarez, V. B., Wolters, C. L., Vodvotz, Y and Ji, T.(2005).Physical properties of ice cream containing Milk protein concentrates. Journal Dairy Science, Champaign, 88: (3): $862-871$.

[10] Maroulis, Z. B., Saravacos, G. D. (2008).Food Plant Economics, New York: CRC Press - Taylor \& Francis Group, 353.

[11] Lucena, M. E., Alvarez, S., Menéndez, C., Rieira, F. A and Alvarez, R. (2007). $\alpha$-LactoalbuminPrecipitation From Commercial Whey Protein Concentrates. Journal Separation and Purification Technology, 52:446-453.

[12] Antunes, A. J. (2003).Funcionalidade de proteínas do soro de leite bovino. Barueri: Manole, 135.

[13] Voorbergen, M., Zwanenberg, A. (2002). Whey-ing up the future. Dairy Industries International,67: (1):25-28.
[14] Antunes, A. E. C., Cazetto, T. F and Bolini, H. M. A.(2004). Skim yogurts added by whey protein concentrate: texture profile, syneresis and sensorial analysis. RevistaAlimentos

[15] e Nutrição, Araraquara, 15: (2):105-114.

[16] Capriles, V.D., Arêas, J. A. G. (2005). Desenvolvimento de salgadinhos com teores reduzidos de gordura saturada e de ácidos graxos trans. Revista Ciência e Tecnologia de Alimentos, Campinas, 25: (2):363-369.

[17] Vermunt, S. H. F., Schaafsma, G and Kardinaal, A. F. M. (2003). Effects of sugar intake on body weight: a review. Obesity Reviews, 2:(4):91- 99.

[18] Armondes, M. P., Issy, P, N., André M. C. D. P. B and Serafini, A. B.(2003). Aspectos higiênico-sanitário de sorvetes e caldas de sorvetes produzidos artesanalmente na cidade de Goiânia, GO. RevistaHigiene Alimentar, São Paulo, 17: (107):86-94.

[19] Carvalho, E. P., Abreu, L. R and Carvalho, M. C. (1995). Estudo de alguns aspectos microbiológicos em sorvetes não pasteurizados. Revista do Instituto de Laticínios "Cândido Tostes", 50:(291):43-49.

[20] Pinto, M. F., Ponsano, E. H. G., Delbem, A. C. B and De Lara, J. A. F, (2000). Condição Higiênico - sanitária de sorvetes fabricados por indústrias artesanais no Município de Araçatuba. RevistaHigiene Alimentar, 14:(72):50-52.

[21] Hoffmann, F. L., Penna, A. L. B and Coelho, A. R. (2000).Qualidade higiênico-sanitária de sorvetes comercializados na cidade de São José do Rio Preto (SP) Brasil. RevistaHigiene Alimentar, São Paulo, 11:(76):62-68.

[22] Borszcz,V. (2002).Implantação do Sistema APPCC para Sorvetes: Aplicação na Empresa Kimyto. 2002. Dissertação (Mestrado em Engenharia de Alimentos) - Universidade Federal de Santa Catarina, Florianópolis.

[23] Diogo, G. T., Aguiar, G. M., Tolentino, M. C., Buffara, D and Pileggi, M. (2002). Avaliação microbiológica de sorvetes comercializados na cidade de Ponta Grossa - PR e da água usada na limpeza das colheres utilizadas para servilos. Biological and Health Sciences, 08:(01):29-30.

[24] Chaves, J. B. P. (1993). Noções de microbiologia e conservação de alimentos, Viçosa: ed. Universidade Federal de Viçosa, 114.

[25] BRASIL, Ministério da Saúde. Agência Nacional de Vigilância Sanitária.(2003 ${ }^{\mathrm{a}}$ ). Resolução RDC n ${ }^{\circ} .267$, de 25 de setembro de 2003. Aprova Regulamento Técnico de Boas Práticas de Fabricação para Estabelecimentos Industrializadores de Gelados Comestíveis. Diário Oficial [da] República Federativa do Brasil, Pode executivo, Brasília, DF, 23 set.

[26] BRASIL, Ministério da Agricultura e Abastecimento. (2003). Secretaria de Defesa agropecuária Instrução Normativa $\mathrm{n}^{\circ}$ 62, de 26 de agosto de 2003. Dispõe dos Métodos Analíticos Oficiais Microbiológicos para Análises Microbiológicas para Controle de Produtos de Origem Animal e Água. Diário Oficial da União - DOU 18 de setembro.

[27] BRASIL, Ministério da Saúde, Agência Nacional de Vigilância Sanitária. (2001). Resolução RDC nº . 12, de 02 de Janeiro de 2001. Aprova regulamento técnico sobre padrões microbiológicos para alimentos. Diário Oficial da República Federativa do Brasil, Brasília, 02 de janeiro. 
[28] Almeida, P. M. P., Franco, R. M. (2003). Avaliação bacteriológica de queijo tipo Minas frescal com pesquisa de patógenos importantes à saúde pública: Staphylococcus aureus, Salmonellasspe Coliformes fecais - RevistaHigiene Alimentar, 17:79-85.

[29] Santos, M. V. (2007). Contagem de psicrotróficos influencia vida de prateleira do leite UAT Availableat www.milkpoint.com.br/?noticiaID=34779\&actA=7\&areaID $=61 \&$ secaoID=180 Accessedon: 11 out.

[30] Beloti, V., Barros, M. A. F, Santana, E. H. W., Pereira, M. S., Moraes, L. B and Gusmão, V. V. (2001). Utilização de bolores e leveduras como indicadores de contaminação na cadeia produtiva de leite em propriedades da região de Londrina, Paraná. XXI Congresso Brasileiro de Microbiologia. Foz do Iguaçu-PR, 377.

[31] Giombelli, A. (2000). Método tradicional clássico para detecção de Salmonella em alimentos: um problema técnico bastante complexo. In: Revista Higiene alimentar, 14:58-61.

[32] Stamford, T. L. M., Silva, C. G. M, Mota,R. A and Cunha, N. A. (2006). Enterotoxigenicidade de Staphylococcus spp. Isolados de leite in natura. Revista Ciência e Tecnologia de Alimentos. Campinas, 26:(1):41- 45.

[33] Zafalon, L. F., Langoni, H., Benvenuto, F., Castelani, L and Broccolo, C. R. (2008). Aspectos epidemiológicos da mastite bovina causada por Staphylococcus aureus. Veterinária e Zootecnia. 15: (1):56-65.

[34] Roos, T. B., Filho, V. B. S., Timm, C. D and Oliveira, D. S. (2005). Avaliação microbiológica de requeijão colonial produzido na cidade de Três Passos, RS. Revista Higiene Alimentar, 19.

[35] Richards, N. S. P. S., Silva, M. E., Pereira, D., Santos, F. I., Fleck, A and Coutinho, M. P. M. D. (2002). Avaliação das condições higiênico sanitárias de sorvetes

[36] etes tipo italiano (soft), comercializados na cidade de São Leopoldo, RS. RevistaHigiene Alimentar,16:(92-93):57-62.

[37] Gomes, D. M., Mendes, L. T., Basto, K. P. L., Povoa, H. C. C and Aredes, E. M. (2006). Detecção de microrganismos em sorvetes fabricados e comercializados no município de Muriaé - MG e região. Revista Científica da Faminas, 02:(01):34-35.

[38] Marques, S. C. (2005). Formação de biofilmes por Staphylococcus aureus na superfície de aço inoxidável e vidro e sua resistência a sanificantes químicos. Lavras-MG, Brasil. Dissertação de mestrado. Mestrado em Ciência dos Alimentos.

[39] Carmo, L. S., Cummings, C., Linardi, V. R., Dias, R. S., Souza, J. M., Sena, M. J., Santos, D. A., Shupp, J. W, Pereira, R. K. P and Jett, M. A. (2004).Case study of a massive Staphylococcal food poisoning incident. Foodborne pathogens and disease, 1: (4):241-246.

[40] Leite, M. M. D., Lima, M. G and Reis, R. B. (2005). Ocorrência de Staphylococcus aureus em queijo Minas tipo frescal. MT.RevistaHigiene Alimentar, 19:(132):89-93.

[41] Silva, A. B. P., Couto, S. M and Tortora, C. O. (2006). O controle microbiológico dos manipuladores, como indicativos da necessidade de medidas corretivas higiênicosanitárias, em restaurante comercial.RevistaHigiene Alimentar, 20:36-39.

[42] Rizzo-Benato, R. T. (2004).Qualidade microbiológica do leite e do sorvete de massa deuma indústria de pequeno porte do município de Piracicaba - SP. São Paulo-SP, Brasil: Dissertação(Mestrado em Ciências) - Escola Superior de Agricultura Luiz de Queiroz, Universidade de SãoPaulo.

[43] Silveira, H. G., Queiroz, N. A. S., Neta, R. S. P., Rodrigues, M. C. P and Costa, J. M. C. (2009). Avaliação da Qualidade físico-química e microbiológica de sorvetes do tipo tapioca. Revista Ciência Agronômica, Fortaleza, 40:(01):60-65.

[44] El-Sharef,N., Ghenghesh,K. S., Abognah, Y. S.,Gnan, S. O and Rahouma, A.(2006).Bacteriological quality of ice cream in Tripoli-Libya. Food Control, 17:(08):637-641.

[45] Okura, M. H., Araujo, P. F., Jardim, F. B. B., Silva, R. R and Finzer, J. R. D. (2006). Influência da atmosfera modificada sobre a qualidade do queijo Minas Frescal. Uberaba. RevistaHigiene Alimentar, 20:84-91.

[46] Ferrari, R. G., Winkler, S.M., and Oliveira, T. C. R. M. (2007).Análise microbiológica de alimentos isentos de registro no Ministério da Saúde. Semina: RevistaCiênciasAgrárias, 28:(2):241-250.

[47] Sena, M. J. (2000). Perfil epidemiológico, resistência a antibióticos e aos conservantes nisina e sistema lactoperoxidase de Staphylococcus spp. isolados de queijos coalho comercializados em Recife-PE, Brasil. 75 f. Tese (Doutorado em Ciência Animal) - Universidade Federal de Minas Gerais, Belo Horizonte.

[48] Bryan, F. L, Teufel, P and Riaz, S. (2001). Hazards and critical control points of street-vending operations in a mountain resort town in Pakistan. Journal Food Protection, 55:(09):701-707.

[49] Velazquez, M., Feirtag, J. M., and Tatini,S. R. (2000).Evaluation of a two-step protocol for rapid detection of Salmonella in ice-cream and Cheddar cheese. Food Microbiology, 17:(03) 349-359.

[50] Kanbakan,U., Con, A. H and Ayar, A. (2004)Determination of microbiological contamination sources during ice cream production in Denizli, Turkey. Food Control. 15:(06):463470 . 